Scientific paper

\title{
New Method of Synthesis of Oligoetherols with Carbazole Ring
}

\author{
Renata Lubczak \\ Rzeszów University of Technology, Department of Organic Chemistry, Al. Powstañców \\ Warszawy 6, 35-959 Rzeszów, Poland \\ *Corresponding author: E-mail: rlubczak@prz.edu.pl
}

Received: 12-12-2014

\begin{abstract}
The new method of synthesis of multifuntional oligoetherols with carbazole ring suitable for obtaining the polyurethane foams of enhanced thermal resistance was presented. At the first step of the synthesis the carbazole was reacted with excess glycidol to obtain the product of $(n+1)$ functionality, where $n$ is number of equivalents of glycidol reacted with carbazole. This semiproduct was then reacted with oxiranes like ethylene and propylene oxides or alkylene carbonates like ethylene and propylene carbonates. The progress of reaction as well as structure of the products were studied by classic and instrumental methods like elemental analysis, IR, ${ }^{1} \mathrm{H}-\mathrm{NMR}$, and MALDI-ToF spectroscopies. Some physico-chemical properties of the products were described.
\end{abstract}

Keywords: Carbazole, glycidol, hydroxyalkylation, oligoetherols, structure, properties

\section{Introduction}

Carbazole is aromatic three ring heterocycle. Chemical properties are similar to other nitrogen-containing heterocycles like indole, pyrrol and secondary aromatic amines. It is weakly acidic due to the presence of nitrogen-attached hydrogen. ${ }^{1}$ Carbazole and its derivatives are used in chemistry and technology of polymers, dyes, herbicides, surfactants, and other polymer additives. ${ }^{2-8}$ Some derivatives of carbazole reveal unique physical properties like photo- and electroluminescence, liquid crystallinity, electric conductance, and nonlinear optical properties. ${ }^{9-15}$ Their properties render them promising structural component in electronic devices and related areas. Carbazole ring is thermally resistant; its decomposition starts at $260{ }^{\circ} \mathrm{C}$. Introducing the carbazole into oligoetherols results in increase of thermal resistance of oligoetherols as well as polyurethanes and polyesters obtained from them. ${ }^{16-22}$ Because carbazole is monofunctional compound it cannot be applied straightforward to get the oligoetherols. Up to date, the attempts to increase its functionality resulted in formation of products which were difficult to isolate and purify. Thus the linear oligoetherols were obtained by its reaction with glycerol epichlorhydrin to give 9-(2,3-epoxypropyl)carbazole followed by epoxide ring opening with water, ethylene glycol or ethanolamine, and further con- version by reaction with oxiranes to get finally bi-functional oligoetherols. ${ }^{16-18}$ In another procedure the oligoetherols were obtained in multistep reaction sequence: the reaction of carbazole with ethylene chloride, then with diethanolamine to get diol, which finally was reacted with oxiranes. ${ }^{18}$ Initially obtained 9-(2,3-epoxypropyl)carbazole was also converted into multifunctional product by ring opening with glycerol or sorbitol. ${ }^{20,22}$ These products were then hydroxyalkylated with oxiranes and further used to obtain linear polyurethanes (PU) and PU foams of good thermal resistance. The multistep procedure can be simplified by using the excess glycidol reacting with carbazole.

Here the protocol leading to multifunctional derivatives (oligoetherols) is described, together with the structure and properties of products, which are suitable substrates to obtain PU foams of enhanced thermal resistance.

\section{Experimental Section}

\section{1. Syntheses}

\section{1. 1. Reactions of Carbazole with Glycidol}

Carbazole (4.2 g, $0.025 \mathrm{~mol}), 1.85-12.95 \mathrm{~g}(0.025-$ $0.200 \mathrm{~mol}$ ) glycidol and $5 \mathrm{~g} \mathrm{~N}, \mathrm{~N}$-dimethylformamide (DMF as solvent) were placed in three-necked $100 \mathrm{~cm}^{3}$ 
flask equipped with mechanical stirrer, reflux condenser and thermometer. The content was heated up to $120{ }^{\circ} \mathrm{C}$. The exothermic reaction was initiated and temperature of the mixture raised to $145{ }^{\circ} \mathrm{C}$ at which the process was continued. In another protocol the reaction was performed at $120{ }^{\circ} \mathrm{C}$ using more DMF $(10 \mathrm{~g})$. The reaction progress was followed by determination of epoxide number (EN). After the reaction mixture was cooled down to room temperature the precipitate was formed. Water $\left(50 \mathrm{~cm}^{3}\right)$ was added and the mixture was heated until the precipitate turned to resin. Upon cooling down the precipitate formed again, which was filtered off, washed with water and vacuum dried. The filtrate was concentrated by evaporation of water; from the filtrate second batch of product was obtained, which was worked up in analogous way.

\section{1. 2. Synthesis of Semiproduct for Synthesis of Oligoetherols}

Carbazole (10.0 g, $0.06 \mathrm{~mol})$ and $12.0 \mathrm{~g}(0.16 \mathrm{~mol})$ DMF were placed in three-necked $250 \mathrm{~cm}^{3}$ flask equipped with mechanical stirrer, reflux condenser and thermometer. The mixture was stirred and heated till carbazole (C) was dissolved $\left(93^{\circ} \mathrm{C}\right)$. To this mixture $31.1 \mathrm{~g}(0.42 \mathrm{~mol})$ glicydol (GL) was added in one portion. The mixture was kept at $120{ }^{\circ} \mathrm{C}$ for one hour. The progress of reaction was controlled by determination of unreacted glycidol and EN. Then the solvent was removed under reduced pressure $(\mathrm{p}=12 \mathrm{hPa})$.

\section{1. 3. Reaction of Semiproduct with Oxiranes}

The product of reaction $\mathrm{C}: \mathrm{Gl}=1: 7(30.0 \mathrm{~g}, 0.044$ $\mathrm{mol})$, triethylamine as catalyst $\left(2 \mathrm{~cm}^{3}, 0.014 \mathrm{~mol}\right)$, and propylene oxide (PO, $21.7 \mathrm{~g}, 0.368 \mathrm{~mol})$ or in another synthesis $10.5 \mathrm{~g} \mathrm{PO}(0.178 \mathrm{~mol})$ and then ethylene oxide (EO, $12.0 \mathrm{~g}, 0.273 \mathrm{~mol}$ ) were placed in $100 \mathrm{~cm}^{3}$ pressure reactor equipped with magnetic stirrer and thermometer. The mixture was stirred and kept at $55-65{ }^{\circ} \mathrm{C}$. The completion of reaction was determined by EN measurement.

\section{1. 4. Reactions of Semiproduct with Alkylene Carbonates}

The product of reaction $\mathrm{C}: \mathrm{Gl}=1: 7(38.0 \mathrm{~g}, 0.055$ mol), potassium carbonate catalyst $\left(0.1 \mathrm{~g}, 7,25 \cdot 10^{-4} \mathrm{~mol}\right)$, and ethylene carbonate (EC, $39.0 \mathrm{~g}, 0.44 \mathrm{~mol}$, to keep initial molar ratio of reagents as 1:8) or propylene carbonate (PC, $34.9 \mathrm{~g}, 0.342 \mathrm{~mol}$, to keep initial molar ratio of reagents as 1:6) were placed in three necked $250 \mathrm{~cm}^{3}$ flask equipped with stirrer, thermometer and reflux condenser. The mixture was heated up and kept at $180^{\circ} \mathrm{C}$ until dissolving of substrate. The reaction progress was checked using mass balance and determination of amount of unreacted alkylene carbonate.

\section{2. Analytical Methods}

The progress of reactions with oxiranes and glycidol were monitored by determination of epoxide number using hydrochloric acid in dioxane method. ${ }^{23}$ The course of reaction between semiproduct and EC or PC was followed by measuring the content of unreacted alkylene carbonate. ${ }^{24}$ Elemental analysis for $\mathrm{C}, \mathrm{H}, \mathrm{N}$, were done with EA 1108, Carlo-Erba analyzer. The IR spectra of products were recorded with Specord 71 IR, Carl Zeiss spectrophotometer in capillary film or in $\mathrm{KBr}$ pellet; the ${ }^{1} \mathrm{H}-\mathrm{NMR}$ spectra were recorded at $500 \mathrm{MHz}$, BECKMAN DU-640 spectrometer in $\mathrm{d}_{6}$-DMSO, with HMDS internal reference. MALDI ToF (Matrix-Assisted Laser Desorption Ionization Time of Flight) of oligoetherols were obtained with BRUKER Autoflex Speed (Bruker Daltonik, Germany) mass spectrometer working at linear mode with delayed ion extraction, equipped with nitrogen laser working at $337 \mathrm{~nm}$. The method of laser desorption from matrix (silver plate) was used. The samples were diluted to $1 \mathrm{mg} / \mathrm{cm}^{3}$ concentration with methanol. Therefore the observed peaks corresponded to the molecular ions plus methanol and $\mathrm{Ag}^{+}$and $\mathrm{K}^{+}$(from catalyst) ions. Thermal analyses of products (DTA, DTG and TG) were performed in ceramic crucible at 20-1000 ${ }^{\circ} \mathrm{C}$ temperature range, about $200 \mathrm{mg}$ sample, under air atmosphere with Termowaga TGA/DSC 1 derivatograph, Mettler.

\section{3. Properties of Oligoetherols}

Refraction index, density, viscosity, and surface tension of oligoetherols were determined with Abbe refractometer, pycnometer, Höppler viscometer and by the detaching ring method, respectively.

\section{Results and Discussion}

Preliminarily the reaction of carbazole with glycidol without solvent was performed at the carbazole : glycidol molar ratio $1: 1-1: 10$. Even upon prolonged heating at $150-190{ }^{\circ} \mathrm{C}$ the mixture remained unreacted. In the presence of TEA catalyst still carbazole remained untouched while glycidol converted into polyglycidol products.

In order to provide homogeneous conditions of reaction the DMF was used as solvent, in which carbazole does dissolve. The advantage of the glycidol substrate is its ability to react with carbazole consecutively as shown in the scheme below:

Initially the reaction was performed at $145^{\circ} \mathrm{C}$ with the C:GL 1:1-1:6 molar ratio mixtures (Table 1). The resin product and precipitate were obtained upon distillation DMF off. The precipitate was identified as carbazole by ${ }^{1} \mathrm{H}-\mathrm{NMR}$ spectroscopy, by presence of characteristic resonance at $11.25 \mathrm{ppm}$ of $\mathrm{NH}$ proton (Fig. 1). Thus, the rest 
<smiles>COC(CO)c1ccc2c3ccc(C(C)OCC(O)CO)cc3n(CC(O)CO)c2c1</smiles>

monofunctional compound<smiles>OCC(O)CC(O)CO</smiles>

3-(9-carbazolyl)propane-1,2-diol (CPD)

- bifunctional compound<smiles>Cn1c2ccccc2c2ccccc21</smiles>

trifunctional compound

Scheme 1. Reaction of carbazole with excess of glycidol

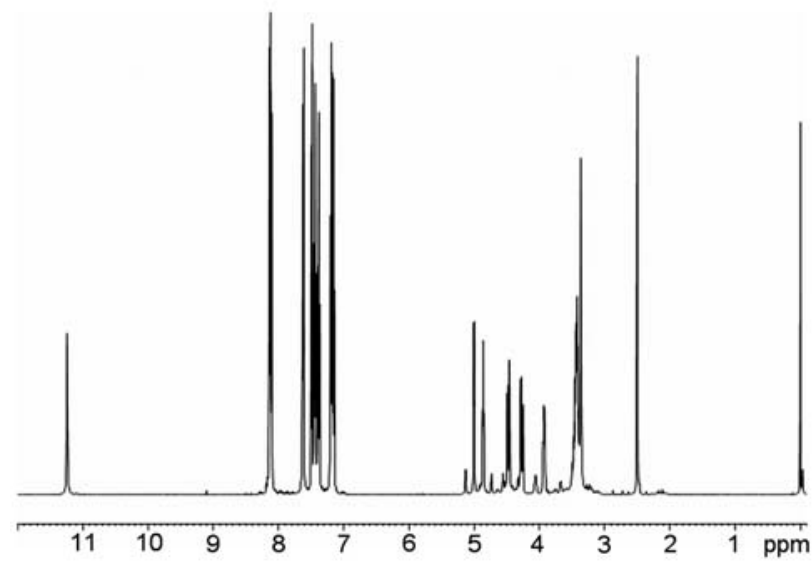

Fig. 1. ${ }^{1} \mathrm{H}-\mathrm{NMR}$ spectrum of post-reaction mixture obtained from the $\mathrm{C}: \mathrm{GL}=1: 1$ molar ratio system of carbazole in post-reaction mixture was converted into bi- and trifunctional consecutive products.

The mixture components were separated as described in Experimental. Based upon nitrogen percentage in carbazole and CPD (the product obtained from C:GL = 1:1 reaction system, see scheme 1), the composition of precipitate and resin was calculated. It has been found that upon increase of glycidol content in reaction system the less precipitate was formed (Table 1, column 8). Thus at the system of 1:7 molar ratio the carbazole no longer precipitated from post-reaction mixture. The nitrogen percentage in precipitate was between 6.3 and 4.7 $\%$, which indicates the presence of unreacted carbazole $(\% \mathrm{~N}=8.38)$ and reaction products $\mathrm{C}: \mathrm{GL}=1: 1(\mathrm{CPD}$, $\% \mathrm{~N}=5.81)$ or $\mathrm{C}: \mathrm{GL}=1: 2(\% \mathrm{~N}=4.44)$ in reaction post-mixture (Table 2, columns 11 and 12). The presence

Table 1. Analysis of reaction progress and products of reaction between carbazole and glycidol

\begin{tabular}{|c|c|c|c|c|c|c|c|c|}
\hline \multirow[t]{2}{*}{ Entry } & \multirow[t]{2}{*}{$\begin{array}{c}\text { C : GL } \\
\text { molar ratio }\end{array}$} & \multicolumn{3}{|c|}{$\begin{array}{l}\text { Composition of } \\
\text { initial mixture } \\
\text { [mass \%] }\end{array}$} & \multirow[t]{2}{*}{$\begin{array}{l}\text { Tempe- } \\
\text { rature } \\
{\left[{ }^{\circ} \mathbf{C}\right]}\end{array}$} & \multirow[t]{2}{*}{$\begin{array}{l}\text { Reaction } \\
\text { time } \\
\text { [min] }\end{array}$} & \multicolumn{2}{|c|}{$\begin{array}{l}\text { Composition of post- } \\
\text { reaction mixture determined } \\
\text { form mass balance }\end{array}$} \\
\hline & & $\mathbf{C}$ & GL & DMF & & & precipitate & resin \\
\hline 1 & 2 & 3 & 4 & 5 & 6 & 7 & 8 & 9 \\
\hline 1 & $1: 1$ & 37.8 & 17.1 & 45.1 & 145 & 30 & 33.7 & 61.3 \\
\hline 2 & $1: 2$ & 32.6 & 28.7 & 38.7 & 145 & 50 & 29.7 & 70.3 \\
\hline 3 & $1: 3$ & 28.4 & 37.8 & 33.8 & 145 & 55 & 17.4 & 82.6 \\
\hline 4 & $1: 4$ & 25.3 & 44.6 & 30.1 & 145 & 60 & 13.6 & 86.4 \\
\hline 5 & $1: 5$ & 22.8 & 50.2 & 27.0 & 145 & 60 & 10.4 & 89.6 \\
\hline 6 & $1: 6$ & 20.6 & 54.9 & 24.5 & 120 & 70 & 6.8 & 93.2 \\
\hline 7 & $1: 6$ & 16.6 & 44.0 & 39.4 & 120 & 105 & 3.1 & 96.9 \\
\hline 8 & $1: 7$ & 18.9 & 58.6 & 22.5 & 120 & 75 & 0.0 & 100 \\
\hline
\end{tabular}


of carbazole in precipitate was confirmed by the resonance of $\mathrm{NH}$ carbazole in the ${ }^{1} \mathrm{H}-\mathrm{NMR}$ spectrum. The ${ }^{1} \mathrm{H}$-NMR spectra of resins did not show this resonance.

Generally the reactivity of glycidol towards hydroxyalkyl derivatives of carbazole is higher in comparison with its reactivity towards carbazole itself. Therefore in order to obtain the products without precipitate the reaction had to be performed with large excess of GL; C:GL 1:n, where $n \geq$ 7. In such protocol the carbazole derivatives containing many hydroxyl groups are formed, which are well soluble in oxirane and react with them in presence of TEA catalyst to give oligoetherols with included carbazole ring.

The product of $\mathrm{C}: \mathrm{GL}=1: 7$ reaction dissolved in PO at $60-70{ }^{\circ} \mathrm{C}$. After addition of TEA into the reaction mixture placed in pressure reactor the multifunctional oligoetherol of $\mathrm{C}: \mathrm{GL}: \mathrm{PO}=1: 7: 8$ molar ratio was obtained. In another reaction the mixture of $\mathrm{PO}$ and $\mathrm{EO}$ was used and the oligoetherol of average composition $\mathrm{C}$ : GL : PO : $\mathrm{EO}=1: 7: 4: 6$ was obtained. In further step the oxiranes were replaced with alkylene carbonates. The semiproduct of $\mathrm{C}: \mathrm{GL}=1: 7$ reaction resulted in formation of analogous products as those obtained with oxiranes, according to the scheme 2:
In contrary to oxiranes, which are cancerogenic and able to form explosive mixture with to air, the alkylene carbonates are not hazardous. ${ }^{25}$ Moreover, alkylene carbonates have lower boiling temperature and thus do not require high pressure reactors. The product of reaction in the $\mathrm{C}: \mathrm{GL}=1: 7$ system is well soluble in alkylene carbonates upon heating to $60-70{ }^{\circ} \mathrm{C}$ and readily react with them in presence of potassium carbonate catalyst to give oligoetherols with incorporated carbazole ring. The process was preformed at $180{ }^{\circ} \mathrm{C}$ within 8 hours. The structure of products (I) is in accordance with elemental analysis results (Table 3 ). The progress of reaction between carbazole and glycidol and further with oxiranes or alkylene carbonates was monitored by IR and ${ }^{1} \mathrm{H}-\mathrm{NMR}$ spectroscopy of substrates, semiproducts and products. In the IR spectrum of carbazole the valence and deformation bands of $\mathrm{NH}$ group were observed at 3419 and $1451 \mathrm{~cm}^{-1}$, respectively. Deformation bands of aromatic $\mathrm{C}-\mathrm{H}$ were found at $757-728 \mathrm{~cm}^{-1}$ region. The $-\mathrm{NH}$ - bands are not present in the IR spectrum of product of reaction performed in the $\mathrm{C}: \mathrm{GL}=1: 7$ system (Fig. 2). Instead the broad band of $-\mathrm{OH}$ group appears, as well as the band at 1100 $\mathrm{cm}^{-1}$ attributed to $\mathrm{C}-\mathrm{OH}$ group. Upon reaction also the et-

Table 2. Elemental analytical results of products of reaction of carbazole with glycidol

\begin{tabular}{|c|c|c|c|c|c|c|c|c|}
\hline \multirow{3}{*}{$\begin{array}{l}\mathbf{C}: \mathbf{G L} \\
\text { molar } \\
\text { ratio }\end{array}$} & \multicolumn{6}{|c|}{ Elemental percentage [mass \%] } & \multirow{3}{*}{$\begin{array}{c}\text { Estimated } \\
\text { composition } \\
\text { of precipitate }\end{array}$} & \multirow{3}{*}{$\begin{array}{c}\text { Estimated } \\
\text { composition } \\
\text { of resin } \mathrm{C}: \mathrm{GL}\end{array}$} \\
\hline & & recipita & & & resin & & & \\
\hline & $\mathbf{N}$ & $\mathbf{C}$ & $\mathbf{H}$ & $\mathbf{N}$ & $\mathbf{C}$ & $\mathbf{H}$ & & \\
\hline 1 & 2 & 3 & 4 & 8 & 9 & 10 & 11 & 12 \\
\hline $1: 1$ & 6.29 & 76.28 & 6.02 & 2.15 & 49.28 & 8.26 & $\begin{array}{c}\text { mixture } \\
\mathrm{C}+\mathrm{CPD}\end{array}$ & $1: 7$ \\
\hline $1: 2$ & 6.28 & 75.34 & 5.99 & 1.20 & 45.02 & 8.56 & $\begin{array}{c}\text { mixture } \\
\mathrm{C}+\mathrm{CPD}\end{array}$ & $1: 13$ \\
\hline $1: 3$ & 5.49 & 71.93 & 6.24 & 1.40 & 50.20 & 8.24 & CPD & $1: 11$ \\
\hline $1: 4$ & 5.57 & 72.78 & 6.90 & 1.42 & 50,30 & 9.19 & CPD & $1: 11$ \\
\hline $1: 5$ & 5.53 & 71.54 & 6.22 & 1.38 & 49.95 & 8.17 & CPD & $1: 12$ \\
\hline $1: 6$ & 4.73 & 67.56 & 6.86 & 1.30 & 50.63 & 8.49 & $\mathrm{C}: \mathrm{Gl}=1: 2$ & $1: 12,5$ \\
\hline $1: 7$ & - & - & - & 2.18 & 55.38 & 8.00 & - & $1: 7$ \\
\hline
\end{tabular}

Calculated elemental percentages [mass \%] Carbazole: N 8.37; C 86.12; H 5.38 CPD: N 5.81: C 74.62; H 6.22 product C:GL = 1:2 : N 4.44: C 68.57 ; H 6.60

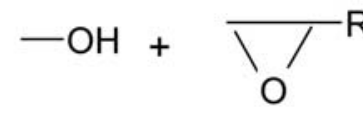<smiles>COCC(C)O</smiles>

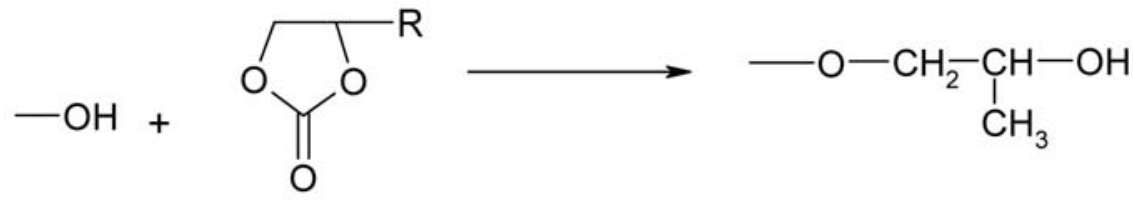

where: $\mathrm{R}=-\mathrm{H},-\mathrm{CH}_{3}$

Scheme 2. Reaction of oxirane and alkylene carbonate with hydroxyl group 


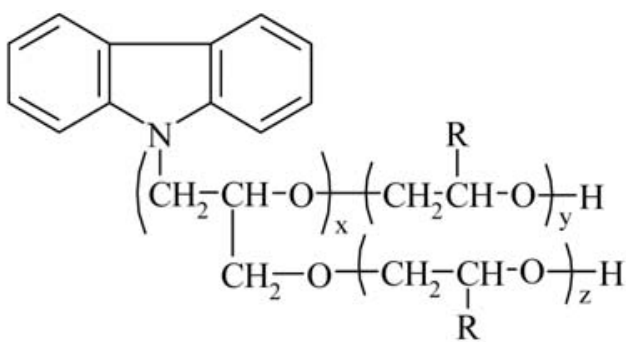

(I)

where: $\mathrm{R}=-\mathrm{H},-\mathrm{CH}_{3}$,

$x=7-$ number of oxyalkylene units from glycidol

$$
z+y=n
$$

n-number of oxyalkylene units from oxirane or alkylene carbonate

Scheme 3. General formula of oligoetherol obtained from carbazole, glycidol and oxiranes or alkylene carbonates

her $\mathrm{C}-\mathrm{O}-\mathrm{C}$ are formed, to which the band at $1039 \mathrm{~cm}^{-1}$ belong. In the product the carbazole ring remains as is evidenced by 753 and $725 \mathrm{~cm}^{-1}$ bands. In the IR spectrum of glycidol the oxirane ring bands is present at $1240 \mathrm{~cm}^{-1}$. This band disappears in the product derived from C:GL = 1:7 system, indicating the glycidol ring opening takes place (Fig. 2).

IR spectra of oligoetherols (Fig. 3) obtained from the semiproduct synthesized in the $\mathrm{C}: \mathrm{GL}=1: 7$ system with oxiranes (EO and PO) or alkylene carbonates (EC, PC) are almost analogous and similar to that of the semi-

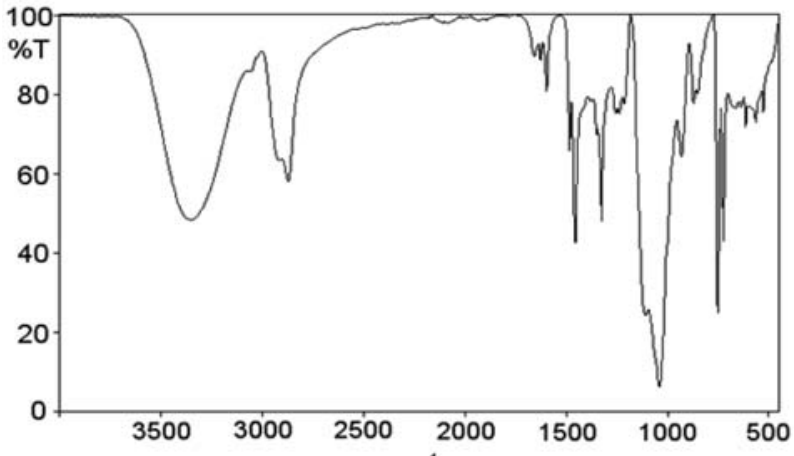

Fig. 2. IR spectrum of product of reaction obtained from the $\mathrm{C}$ : GL $=1: 7$ molar ratio

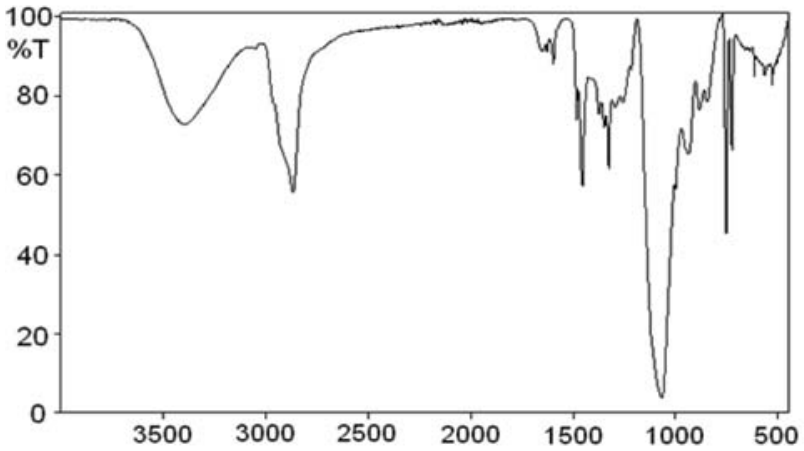

Fig. 3. IR spectrum of oligoetherol obtained from $\mathrm{C}: \mathrm{GL}: \mathrm{EO}: \mathrm{PO}=$ $1: 7: 4: 6$ molar ratio system

product obtained from $\mathrm{C}: \mathrm{GL}=1: 7$. However the band intensity differences are relevant, especially that of the valence $-\mathrm{OH}$ in relation to valence $\mathrm{C}-\mathrm{H}$ band (3051-2869 $\mathrm{cm}^{-1}$ ) and $\mathrm{C}-\mathrm{O}-\mathrm{C}$ band $\left(1078-1067 \mathrm{~cm}^{-1}\right)$. The latter increase in intensity indicating the number of oxyalkylene units grows as a result of ring opening of oxirane and alkylene carbonates. The characteristic bands at 753 and $725 \mathrm{~cm}^{-1}$ in products evidence the presence of carbazole ring in the products.

In the ${ }^{1} \mathrm{H}-\mathrm{NMR}$ spectrum of carbazole the aromatic proton resonances occur at 7.1-8.1 ppm region, while the -NH- proton resonance is present at $11.25 \mathrm{ppm}$. The -NH-

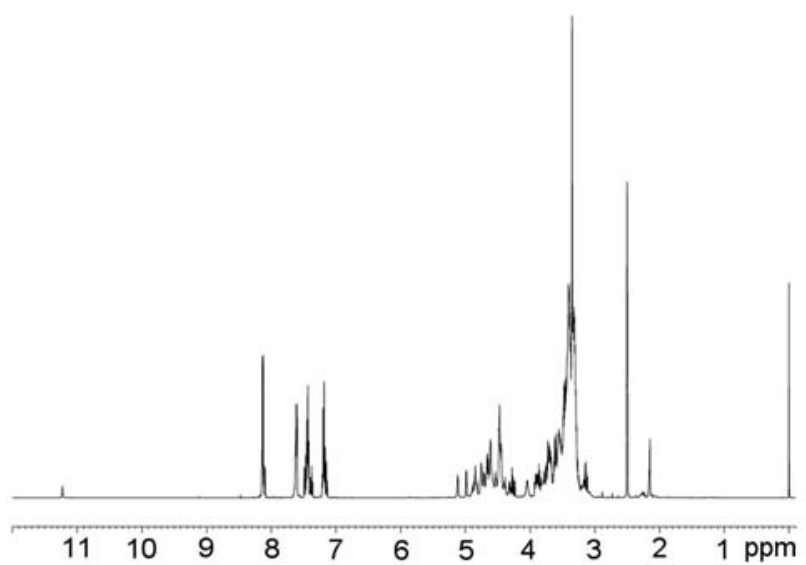

Fig. 4. ${ }^{1} \mathrm{H}-\mathrm{NMR}$ spectrum of semiproduct obtained from $\mathrm{C}: \mathrm{GL}=$ $1: 7$ molar ratio

Table 3. Elemental analysis data of oligoetherols

\begin{tabular}{lcccccc}
\hline Initial reagent molar ratio & \multicolumn{3}{c}{ Elemental percentage [mass \%] } \\
& $\mathbf{C}$ & calculated & $\mathbf{N}$ & $\mathbf{H}$ & $\mathbf{C}$ & determined \\
N & H \\
\hline $\mathrm{C}: \mathrm{GL}=1: 7$ & 57.80 & 2.04 & 7.50 & 57.61 & 2.13 & 7.42 \\
$\mathrm{C}: \mathrm{GL}: \mathrm{EO}: \mathrm{PO}=1: 7: 4: 6$ & 57.13 & 1.26 & 7.15 & 56.96 & 1.37 & 7.32 \\
$\mathrm{C}: \mathrm{GL}: \mathrm{PO}=1: 7: 8$ & 65.43 & 1.34 & 8.77 & 65.60 & 1.29 & 8.52 \\
$\mathrm{C}: \mathrm{GL}: \mathrm{EC}=1: 7: 8$ & 60.75 & 1.65 & 7.49 & 60.69 & 1.42 & 7.30 \\
$\mathrm{C}: \mathrm{GL}: \mathrm{PC}=1: 7: 6$ & 63.87 & 1.66 & 7.89 & 63.75 & 1.59 & 7.80 \\
\hline
\end{tabular}


proton resonance is absent in the spectrum of semiproduct obtained from C:GL = 1:7 (Fig. 4) clearly demon-strating this group has reacted with glycidol. The resonances of methylene and methine protons at 3.2-4.0 ppm region in the spectrum of the semiproduct indicate the glycidol ring opening. The $-\mathrm{OH}$ proton resonances are present in the 4.2-5.2 ppm region attributed to various hydroxyalkyl groups. The $-\mathrm{OH}$ protons could be selectively exchanged to deuterium upon addition of $\mathrm{D}_{2} \mathrm{O}$. Still the carbazole aromatic proton resonances are present within 7.1-8.1 ppm region. In the ${ }^{1} \mathrm{H}-\mathrm{NMR}$ spectra of products of reaction between semiproduct obtained from C: GL = 1:7 system and oxiranes (Fig. 5) the aromatic resonances remain. More complicated spectrum can be seen in the 3.0-4.0 ppm, where oxyalkylene group resonances are present. Moreover, the additional resonances at $0.7-1.2 \mathrm{ppm}$ from methyl groups are observed due to ring opening of PO in the product. The ${ }^{1} \mathrm{H}-\mathrm{NMR}$ spectra of products obtained from semiproduct $\mathrm{C}: \mathrm{GL}=1: 7$ and alkylene carbonates are similar to those obtained from oxiranes indicating the structure of the products is similar in both cases. In the spectra of the products obtained from PC the methyl group proton resonances are observed at 0.9-1.2 ppm.

MALDI-TOF spectra of the products provide more information. In the spectrum the semiproduct obtained from $C: G=1: 7$ the glycidol peak, which $M / z$ is increased by silver ion due to silver plate matrix used (Table 4, entry 2 ). Observed peaks are derived from products with varying degrees of addition of glycidol to carbazole. The peak of highest $\mathrm{M} / \mathrm{z}$ corresponds to the product of $\mathrm{C}: \mathrm{GL}$ $=1: 8$ stoichiometry (Table 4 , entry 18 ). Thus the stoichiometry in the products is not larger then initial molar

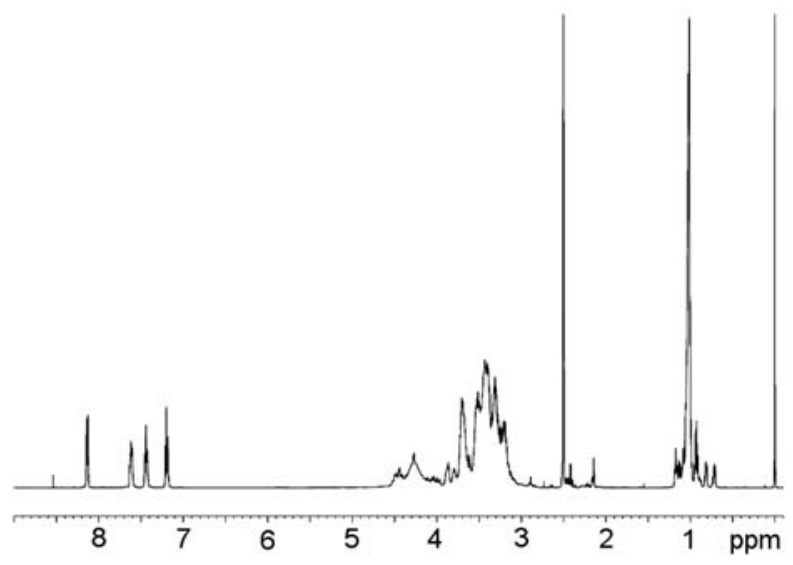

Fig. 5. ${ }^{1} \mathrm{H}-\mathrm{NMR}$ spectrum of oligoetherol obtained from the $\mathrm{C}$ : GL $: \mathrm{EO}: \mathrm{PO}=1: 7: 4: 6$ molar ratio system

ratio of reagents used in synthesis. In the MALDI-TOF spectra of oligoetherols the series of peaks differing of 58 in case of PO substrate and differing of 44 and 58, in case of using both EO and PO substrates are observed (Table 5). In the spectra of oligoetherols the series of peaks are observed differing by number of units originate from glycidol, to which PO is attached providing variable amount of oxypropylene units and then to this product variable amount of EO substrate is attached. Thus the product is a mixture of oligoetherols of different molecular mass. Also in the spectra of oligoetherols obtained from $\mathrm{PC}$ the series of peaks differing by $\mathrm{M} / \mathrm{z}=58$ are observed due to attachment of variable amount of oxypropylene units formed upon PC ring opening. The absence of peak differing by $\mathrm{M} / \mathrm{z}=44$ in the spectrum of

Table 4. MALDI-ToF analysis of product obtained from the $\mathrm{C}: \mathrm{GL}=1: 7$ system

\begin{tabular}{|c|c|c|c|c|}
\hline Entry & $\begin{array}{l}\text { Position of } \\
\text { signal } M / z\end{array}$ & $\begin{array}{l}\text { Relative signal } \\
\text { intensity [\%] }\end{array}$ & $\begin{array}{c}\text { Putative structure } \\
\text { of molecular ion }\end{array}$ & $\begin{array}{c}\text { Calculated molar } \\
\text { mass }[\mathrm{g} / \mathrm{mol}]\end{array}$ \\
\hline 1 & 106.9 & 25.8 & $\mathrm{Ag}^{+}$ & 107 \\
\hline 2 & 180.2 & 100 & $\mathrm{GL}+\mathrm{Ag}^{+}$ & 181 \\
\hline 3 & 241.1 & 84.3 & $\mathrm{C}+\mathrm{GL}$ & 241 \\
\hline 4 & 297.1 & 84.3 & $\mathrm{C}+2 \mathrm{GL}-\mathrm{H}_{2} \mathrm{O}$ & 297 \\
\hline 5 & 315.1 & 83.2 & $\mathrm{C}+2 \mathrm{GL}$ & 315 \\
\hline 6 & 347.9 & 4.5 & $\mathrm{C}+\mathrm{GL}+\mathrm{Ag}^{+}$ & 348 \\
\hline 7 & 389.2 & 29.2 & $\mathrm{C}+3 \mathrm{GL}$ & 389 \\
\hline 8 & 422.2 & 6.7 & $\mathrm{C}+2 \mathrm{GL}+\mathrm{Ag}^{+}$ & 422 \\
\hline 9 & 463.6 & 5.6 & $\mathrm{C}+4 \mathrm{GL}$ & 463 \\
\hline 10 & 496.8 & 5.6 & $\mathrm{C}+3 \mathrm{GL}+\mathrm{Ag}^{+}$ & 496 \\
\hline 11 & 538.3 & 2.3 & $\mathrm{C}+5 \mathrm{GL}$ & 537 \\
\hline 12 & 554.7 & 2.3 & $\mathrm{C}+5 \mathrm{GL}+\mathrm{H}_{2} \mathrm{O}$ & 535 \\
\hline 13 & 572.0 & 4.5 & $\mathrm{C}+4 \mathrm{GL}+\mathrm{Ag}^{+}$ & 572 \\
\hline 14 & 630.4 & 1.1 & $\mathrm{C}+5 \mathrm{GL}-\mathrm{H}_{2} \mathrm{O}+\mathrm{Ag}^{+}$ & 628 \\
\hline 15 & 647.9 & 2.3 & $\mathrm{C}+5 \mathrm{GL}^{2}+\mathrm{Ag}^{+}$ & 646 \\
\hline 16 & 704.8 & 1.1 & $\mathrm{C}+6 \mathrm{GL}-\mathrm{H}_{2} \mathrm{O}+\mathrm{Ag}^{+}$ & 703 \\
\hline 17 & 804.1 & 1.1 & $\mathrm{C}+7 \mathrm{GL}+\mathrm{Ag}^{+}+\mathrm{H}_{2} \mathrm{O}$ & 810 \\
\hline 18 & 880.3 & 1.1 & $\mathrm{C}+8 \mathrm{GL}+\mathrm{Ag}^{+}+\mathrm{H}_{2} \mathrm{O}$ & 884 \\
\hline
\end{tabular}

GL-oxyalkylene group form ring decomposition of glycidol 
the product obtained from $\mathrm{PC}$, corresponding to - $\mathrm{COO}-$ fragment clearly indicates the absence of carboxyl group in oligoetherol. Therefore, the reaction does not occur according to the scheme 4 :<smiles>CC(CO)COC(=O)OCCCCCCC(=O)OC(C)CO</smiles>

Scheme 4. Reaction of hydroxyl group with propylene carbonate to form the ester group

Table 5. MALDI-ToF analysis of oligoetherol obtained from the $\mathrm{C}: \mathrm{GL}: \mathrm{PO}: \mathrm{EO}=1: 7: 4: 6$ molar ratio

\begin{tabular}{|c|c|c|c|c|}
\hline Entry & $\begin{array}{l}\text { Position of } \\
\text { signal } M / z\end{array}$ & $\begin{array}{c}\text { Relative signal } \\
\text { intensity [\%] }\end{array}$ & $\begin{array}{c}\text { Putative structure } \\
\text { of molecular ion }\end{array}$ & $\begin{array}{c}\text { Calculated molar } \\
\text { mass [g/mol] }\end{array}$ \\
\hline 1 & 248.1 & 100 & $\mathrm{C}+\mathrm{GL}-\mathrm{H}_{2} \mathrm{O}+\mathrm{Na}^{+}$ & 246 \\
\hline 2 & 262.2 & 56.5 & $\mathrm{C}+\mathrm{GL}+\mathrm{Na}^{+}$ & 264 \\
\hline 3 & 273.2 & 43.1 & $\mathrm{C}+\mathrm{GL}+\mathrm{CH}_{3} \mathrm{OH}$ & 273 \\
\hline 4 & 276.1 & 27.9 & $\mathrm{C}+\mathrm{GL}+\mathrm{H}^{+}+\mathrm{CH}_{3} \mathrm{OH}$ & 274 \\
\hline 5 & 278.0 & 92.4 & $\mathrm{C}+\mathrm{GL}+\mathrm{Na}^{+}$ & 278 \\
\hline 6 & 292.2 & 99.0 & $\mathrm{C}+\mathrm{GL}+\mathrm{EO}^{-} \mathrm{H}_{2} \mathrm{O}+\mathrm{Na}^{+}$ & 290 \\
\hline 7 & 299.2 & 8.4 & $\mathrm{C}+\mathrm{GL}+\mathrm{PO}$ & 299 \\
\hline 8 & 306.1 & 25.8 & $\mathrm{C}+\mathrm{GL}+\mathrm{PO}-\mathrm{H}_{2} \mathrm{O}+\mathrm{Na}^{+}$ & 304 \\
\hline 9 & 308.2 & 11.4 & $\mathrm{C}+\mathrm{GL}+\mathrm{EO}+\mathrm{Na}^{+}$ & 308 \\
\hline 10 & 322.2 & 38.3 & $\mathrm{C}+\mathrm{GL}+\mathrm{PO}+\mathrm{EO}-\mathrm{H}_{2} \mathrm{O}$ & 325 \\
\hline 11 & 336.3 & 79.7 & $\mathrm{C}+2 \mathrm{GL}+\mathrm{Na}^{+}$ & 338 \\
\hline 12 & 338.1 & 14.8 & $\mathrm{C}+\mathrm{GL}+2 \mathrm{PO}-\mathrm{H}_{2} \mathrm{O}$ & 339 \\
\hline 13 & 343.1 & 16.0 & $\mathrm{C}+\mathrm{GL}+\mathrm{PO}+\mathrm{EO}$ & 343 \\
\hline 14 & 350.2 & 12.8 & $\mathrm{C}+\mathrm{GL}+\mathrm{PO}+\mathrm{EO}-\mathrm{H}_{2} \mathrm{O}+\mathrm{Na}^{+}$ & 348 \\
\hline 15 & 352.0 & 11.8 & $\mathrm{C}+2 \mathrm{GL}+\mathrm{PO}-\mathrm{H}_{2} \mathrm{O}$ & 355 \\
\hline 16 & 357.2 & 29.8 & $\mathrm{C}+2 \mathrm{GL}+\mathrm{PO}$ & 357 \\
\hline 17 & 366.1 & 22.4 & $\mathrm{C}+\mathrm{GL}+\mathrm{PO}+\mathrm{EO}+\mathrm{Na}^{+}$ & 366 \\
\hline 18 & 369.1 & 14.8 & $\mathrm{C}+\mathrm{GL}+\mathrm{PO}+\mathrm{EO}-\mathrm{H}_{2} \mathrm{O}$ & 369 \\
\hline 19 & 373.2 & 11.0 & $\mathrm{C}+2 \mathrm{GL}+\mathrm{PO}$ & 373 \\
\hline 20 & 380.3 & 37.1 & $\mathrm{C}+\mathrm{GL}+2 \mathrm{PO}+\mathrm{Na}^{+}$ & 380 \\
\hline 21 & 431.3 & 18.1 & $\mathrm{C}+\mathrm{GL}+\mathrm{PO}+\mathrm{EO}$ & 431 \\
\hline 22 & 441.1 & 28.9 & $\mathrm{C}+\mathrm{GL}+2 \mathrm{PO}+\mathrm{EO}-\mathrm{H}_{2} \mathrm{O}$ & 441 \\
\hline 23 & 457.0 & 5.4 & $\mathrm{C}+\mathrm{GL}+\mathrm{PO}+4 \mathrm{EO}-\mathrm{H}_{2} \mathrm{O}$ & 457 \\
\hline 24 & 461.) & 5.4 & $\mathrm{C}+\mathrm{GL}+3 \mathrm{PO}+\mathrm{EO}+\mathrm{H}^{+}$ & 460 \\
\hline 25 & 471.0 & 8.0 & $\mathrm{C}+\mathrm{GL}+2 \mathrm{PO}+3 \mathrm{EO}-\mathrm{H}_{2} \mathrm{O}$ & 471 \\
\hline 26 & 475.3 & 10.6 & $\mathrm{C}+2 \mathrm{GL}+2 \mathrm{PO}+\mathrm{EO}$ & 475 \\
\hline 27 & 489.3 & 8.0 & $\mathrm{C}+2 \mathrm{GL}+\mathrm{PO}+3 \mathrm{EO}-\mathrm{H}_{2} \mathrm{O}+\mathrm{H}^{+}$ & 488 \\
\hline 28 & 505.3 & 12.4 & $\mathrm{C}+2 \mathrm{GL}+\mathrm{PO}+3 \mathrm{EO}$ & 505 \\
\hline 29 & 582.8 & 7.8 & $\mathrm{C}+2 \mathrm{GL}+3 \mathrm{PO}+2 \mathrm{EO}-\mathrm{H}_{2} \mathrm{O}+\mathrm{Na}^{+}$ & 582 \\
\hline 30 & 592.2 & 10.0 & $\mathrm{C}+3 \mathrm{GL}+2 \mathrm{PO}+2 \mathrm{EO}$ & 593 \\
\hline 31 & 606.1 & 9.0 & $\mathrm{C}+2 \mathrm{GL}+2 \mathrm{PO}+4 \mathrm{EO}$ & 607 \\
\hline 32 & 607.4 & 11.6 & $\mathrm{C}+2 \mathrm{GL}+2 \mathrm{PO}+4 \mathrm{EO}$ & 607 \\
\hline 33 & 620.2 & 12.6 & $\mathrm{C}+3 \mathrm{GL}+2 \mathrm{PO}+3 \mathrm{EO}-\mathrm{H}_{2} \mathrm{O}+\mathrm{H}^{+}$ & 620 \\
\hline 34 & 621.4 & 9.3 & $\mathrm{C}+5 \mathrm{GL}+\mathrm{PO}+\mathrm{EO}^{-} \mathrm{H}_{2} \mathrm{O}$ & 621 \\
\hline 35 & 637.4 & 8.6 & $\mathrm{C}+3 \mathrm{GL}+2 \mathrm{PO}+3 \mathrm{EO}$ & 637 \\
\hline 36 & 650.4 & 6.4 & $\mathrm{C}+3 \mathrm{GL}+3 \mathrm{PO}+2 \mathrm{EO}$ & 651 \\
\hline 37 & 681.1 & 6.6 & $\mathrm{C}+3 \mathrm{GL}+2 \mathrm{PO}+4 \mathrm{EO}$ & 681 \\
\hline 38 & 695.0 & 5.8 & $\mathrm{C}+3 \mathrm{GL}+3 \mathrm{PO}+3 \mathrm{EO}$ & 695 \\
\hline 39 & 755.5 & 4.2 & $\mathrm{C}+3 \mathrm{GL}+4 \mathrm{PO}+3 \mathrm{EO}+\mathrm{H}^{+}$ & 754 \\
\hline \multirow[t]{2}{*}{40} & 769.5 & 3.1 & $\mathrm{C}+4 \mathrm{GL}+3 \mathrm{PO}+3 \mathrm{EO}$ & 769 \\
\hline & & & $\mathrm{C}+7 \mathrm{GL}+\mathrm{PO}+\mathrm{EO}-\mathrm{H}_{2} \mathrm{O}$ & 769 \\
\hline
\end{tabular}

GL, PO, EO-oxyalkylene group originate from ring decomposition of glycidol, propylene and ethylene oxides, respectively 
This is confirmed by the IR and H-NMR spectrum of the product obtained from PC, which is analogous to that obtained from PO. The semiproduct obtained from carbazole and glycidol loses water, especially when the process is conducted at high temperature $\left(120-145^{\circ} \mathrm{C}\right.$; Table 5, entries .8, 10, 12, 14, 15,18, 22, 23, 25, 27, 33, 34, 40). This process in undesired, because it leads to formation of unsaturated fragment according to the scheme below:<smiles>CCC(O)CO</smiles>

However this process is negligible as can be estimated from the ${ }^{1} \mathrm{H}-\mathrm{NMR}$ spectra of oligoetherols, in which olefin proton resonances are absent.

Thermal analysis of the products (Table 6) indicated that the highest thermal stability showed semiproduct obtained from carbazole and glycidol and the oligoetherols obtained from oxiranes. The $10 \%$ decomposition starts at ca $192-213{ }^{\circ} \mathrm{C}$, and maximum decomposition temperature is $360{ }^{\circ} \mathrm{C}$. Thus thermal resistance of obtained oligoetherols is high. Thermal resistance of oligoetherols obtained from alkylene carbonates is slightly lower. Their decom-position starts already at $130{ }^{\circ} \mathrm{C}$. The lower thermal resistance on these cases in probably related to the presen-

Table 6. Comparison of thermal resistance of oligoetherols

\begin{tabular}{|c|c|c|c|c|c|}
\hline Oligoetherol & $\mathbf{T}_{10 \%}\left[{ }^{\circ} \mathbf{C}\right]$ & $\mathbf{T}_{25 \%}\left[{ }^{\circ} \mathbf{C}\right]$ & $\mathbf{T}_{50 \%}\left[{ }^{\circ} \mathbf{C}\right]$ & $\mathbf{T}_{75 \%}\left[{ }^{\circ} \mathbf{C}\right]$ & $\mathbf{T}_{\text {max. decomposition }}\left[{ }^{\circ} \mathbf{C}\right]$ \\
\hline $\mathrm{C}: \mathrm{GL}=1: 7$ & 192 & 240 & 310 & 352 & 360 \\
\hline $\mathrm{C}: \mathrm{GL}: \mathrm{EO}: \mathrm{PO}=1: 7: 4: 6$ & 213 & 274 & 332 & 367 & 360 \\
\hline $\mathrm{C}: \mathrm{GL}: \mathrm{PO}=1: 7: 8$ & 209 & 274 & 333 & 365 & 310 \\
\hline $\mathrm{C}: \mathrm{GL}: \mathrm{EC}=1: 7: 8$ & 132 & 211 & 328 & 371 & 401 \\
\hline $\mathrm{C}: \mathrm{GL}: \mathrm{PC}=1: 7: 6$ & 160 & 227 & 319 & 366 & 395 \\
\hline
\end{tabular}

$\mathrm{T}_{\mathrm{x} \%}$-temperaturę of $\mathrm{x} \%$ mass loss

Table 7. Physical properties of oligoetherols

\begin{tabular}{|c|c|c|c|c|c|}
\hline Oligoetherol & $\begin{array}{c}\text { Temperature } \\
{\left[{ }^{\circ} \mathbf{C}\right]}\end{array}$ & $\begin{array}{c}\text { Refraction } \\
\text { index } n_{D}\end{array}$ & $\begin{array}{l}\text { Density } \\
{\left[\mathrm{g} / \mathrm{cm}^{3}\right]}\end{array}$ & $\begin{array}{l}\text { Viscosity } \\
{[\mathrm{mPa} \cdot \mathrm{s}]}\end{array}$ & $\begin{array}{c}\text { Surface tension } \\
{[\mathrm{N} / \mathrm{m}] \cdot \mathbf{1 0}^{\mathbf{3}}}\end{array}$ \\
\hline \multirow{7}{*}{$\mathrm{C}: \mathrm{GL}: \mathrm{EO}: \mathrm{PO}=1: 7: 4: 6$} & 20 & 1.5157 & 1.170 & 43682 & 59.5 \\
\hline & 30 & 1.5120 & 1.164 & 15042 & 57.2 \\
\hline & 40 & 1.5090 & 1.156 & 4747 & 54.6 \\
\hline & 50 & 1.5058 & 1.149 & 1867 & 52.3 \\
\hline & 60 & 1.5025 & 1.142 & 841.6 & 49.8 \\
\hline & 70 & 1.4991 & 1.135 & 434.3 & 47.7 \\
\hline & 80 & 1.4964 & 1.128 & 227.7 & 45.6 \\
\hline \multirow{7}{*}{$C: G L: P O=1: 7: 8$} & 20 & 1.5104 & 1.141 & 61301 & 59.9 \\
\hline & 30 & 1.5072 & 1.133 & 16818 & 51.5 \\
\hline & 40 & 1.5038 & 1.124 & 5178 & 44.8 \\
\hline & 50 & 1.5002 & 1.113 & 1957 & 38.9 \\
\hline & 60 & 1.4969 & 1.106 & 1618 & 31.1 \\
\hline & 70 & 1.4936 & 1.099 & 375.1 & 23.6 \\
\hline & 80 & 1.4905 & 1.090 & 180.1 & 17.5 \\
\hline \multirow{7}{*}{ C $:$ GL: $E C=1: 7: 8$} & 20 & 1.5235 & 1.184 & 10928 & 20.00 \\
\hline & 30 & 1.5197 & 1.178 & 4222 & 19.47 \\
\hline & 40 & 1.5158 & 1.171 & 1625 & 19.00 \\
\hline & 50 & 1.5128 & 1.163 & 707.3 & 18.58 \\
\hline & 60 & 1.5089 & 1.155 & 384.1 & 18.16 \\
\hline & 70 & 1.5049 & 1.148 & 205.4 & 17.64 \\
\hline & 80 & 1.5009 & 1.142 & 120.5 & 17.29 \\
\hline \multirow{7}{*}{$C: G L: P C=1: 7: 6$} & 20 & 1.5192 & 1.155 & 26525 & 19.14 \\
\hline & 30 & 1.5162 & 1.149 & 8982 & 18.47 \\
\hline & 40 & 1.5124 & 1.140 & 3630.8 & 17.78 \\
\hline & 50 & 1.5089 & 1.133 & 1513 & 17.15 \\
\hline & 60 & 1.5054 & 1,126 & 642.0 & 16.74 \\
\hline & 70 & 1.5019 & 1,119 & 298.5 & 16.25 \\
\hline & 80 & 1.4988 & 1,113 & 157.7 & 15.76 \\
\hline
\end{tabular}


ce of ethylene or propylene glycols formed during reaction with trace water present in substrates, and also as a result other processes as described in ${ }^{26}$. These glycols are in quantities of a few percent by weight and were isolated from oligoetherols upon distillation under reduced pressure and identified by their IR spectra.

The physical properties of obtained oligoetherols, like: density, surface tension, refraction index and viscosity were measured (Table 7). These properties changed characteristically in function of temperature. It has been found that products obtained from PO have slightly lower density and refraction index in comparison with those obtained from mixture of oxiranes. The difference is probably consistent with lower packing of product due to presence of bulky methyl groups in oxyalkylene units derived from PO. Similar relationship was found in the oligoetherols obtained from PC. Based on the results on viscosity and surface tension it can be concluded that obtained multifunctional oligoetherols are good candidates to obtain polyurethane foams of enhanced thermal resistance.

\section{Conclusions}

1. The simple method of obtaining oligoetherols containing carbazole ring by two step protocol of reaction between carbazole and glycidol and futher with oxiranes or alkylene carbonates was found.

2. Carbazole reacts with glycidol without catalyst. The process is exothermic and thus needs control of temperature. Reaction of carbazole with glycidol requires excess of glycidol, the best C:GL molar ratio is 1:7. When lower excess of GL is used, the carbazole precipitates from reaction mixture.

3. Obtained resin products (semiproducts) are soluble in oxiranes like EO and PO and in alkylene carbonates like EC and PC. Oxiranes and alkylene carbonates react with the semiproduct in presence of TEA or potassium carbonate catalysts, respectively, to give oligoetherols containing carbazole incorporated. The products are potentially useful for synthesis of polyurethane foams of enhanced thermal resistance. ${ }^{27}$

\section{Acknowledgments}

NMR spectra were recorded within U-8689/DS

\section{References}

2. M. D. Shattuck, U. Vahtra, U.K. Patent Number 1,122,458, 1968.

3. K. Kinjo, T. Yamanouchi, K. Fujisawa, E. Kondo, H. Matsuno, K. Nishide, German Patent Number 2,035,679, 1971.

4. E. E. Renfrew, U.S. Patent Number 3,787,178, 1974.

5. K. Nishide, T. Yamanouchi, K. Kinjo, U.S. Patent Number 3,832,172, 1974.

6. A. M. El-Nagger, F. S. M. Ahmed Abd., A. M. El-Salam, M. A. El-Gazzar, J. Heterocycl. Chem., 1982, 19, 1025-1028. http://dx.doi.org/10.1002/jhet.5570190509

7. W. Yang, P. Davis, Drug. Metab. Dispos., 1992, 20, 38-46.

8. H. Spanggaard, M. Jorgensen, K. Almdal, Macromolecules, 2003, 36, 1701-1705. http://dx.doi.org/10.1021/ma0256791

9. Y. Shikatani, Jpn. Patent Number. 01,311,161, 1989.

10. K. Albrecht, Y. Kasai, K. Yamamo, J. Inorg. Organometallic Polym. Mat., 2009, 19, 118-123. http://dx.doi.org/10.1007/s10904-008-9239-3

11. J. A. Gratt, R. E. Cohen, J. Appl. Polym. Sci., 2003, 88, 177-182. http://dx.doi.org/10.1002/app.11620

12. W. Zhu, M. Hu, R. Yao, H. Tian, J. Photochem. Photobiol.: A-Chemistry, 2003, 154, 169-177.

13. J. H. Lee, H. S. Woo, T. W. Kim, J. W. Park, Optical Mat., 2003, 21, 225-229. http://dx.doi.org/10.1016/S0925-3467(02)00141-6

14. X. J. Zhang, Y.P. Tian, S. L. Li, M. Jiang, A. Usman, S. Chantrapromma, H.K. Fun, Polyhedron, 2003, 22, 397-402. http://dx.doi.org/10.1016/S0277-5387(02)01360-8

15. S. Tirapattur, M. Belletete, N. Drolet, N. Leclerc, G. Durocher, Chem. Phys. Lett., 2003, 370, 799-804. http://dx.doi.org/10.1016/S0009-2614(03)00178-7

16. R. Lubczak, Polimery, 2008, 53, 587-590

17. R. Lubczak, J. Appl. Polym. Sci., 2008, 110, 3501-3507. http://dx.doi.org/10.1002/app.28935

18. R. Lubczak, J. Appl. Polym. Sci. 2010, 117, 16-23.

19. R. Lubczak, Open J. Organic Polym. Mat., 2012, 2, 1-6.

20. R. Lubczak, e- Polymers, 2012, 070, 1-11.

21. R. Lubczak, Polym. Inter., 2013, 62, 1243-1249.

22. R. Lubczak, Polymer Bulletin (submitted).

23. Epoxide resins. Method of testing. Determination of the epoxide number and epoxide equivalent. Polish Standards PNC-89085-13:1987, Ed: Polish Committee for Standar-dization, 1987.

24. D. Kijowska, S. Wołowiec, J. Lubczak, J. Appl. Polym. Sci., 2004, 93, 294-300. http://dx.doi.org/10.1002/app.20453

25. D. Kijowska, Przemysl Chemiczny, 2005, 84, 678-683.

26. J. Lubczak, E. Węglowska, Intern. J. Chem. Kin., 2009, 41, 523-531. http://dx.doi.org/10.1002/kin.20427

27. R. Lubczak, Cell. Polym., (in press).

\footnotetext{
1. J. Joule, Adv. Heterocycl. Chem., 1984, 35, 83-198. http://dx.doi.org/10.1016/S0065-2725(08)60149-X
} 


\section{Povzetek}

V prispevku je predstavljena nova metoda sinteze multifunkcijskih oligoeterolov s karbazolnim obročem, ki so primerni za pripravo poliuretanske pene s povečano termično stabilnostjo. V prvi stopnji sinteze karbazol reagira s presežnim glicidolom, pri čemer nastane produkt z $(n+1)$ fukcionalnostjo, kjer $n$ predstavlja število ekvivalentov glicidola, ki reagira s karbazolom. Vmesni produkt nadalje reagira z oksirani, kot sta etilen in propilen oksid, ali alkilen karbonati, kot sta etilen in propilen karbonat. Potek sinteze in produkte reakcije smo spremljali s klasičnimi metodami in instrumentalnimi tehnikami kot so: elementna analiza, IR, ${ }^{1} \mathrm{H}-\mathrm{NMR}$ in MALDI-ToF spektroskopija. V prispevku so opisane tudi nekatere fizikalno kemijske lastnosti produktov. 